\title{
First report of Fusarium wilt caused by Fusarium oxysporum on Cyclamen persicum in Turkey
}

\author{
Mehmet Akif Gültekin ${ }^{1}$ - Zühtü Polat ${ }^{1}$ - Gülsüm Palacıoğlu ${ }^{2} \cdot$ Harun Bayraktar ${ }^{2}$ (])
}

Received: 14 August 2021 / Accepted: 26 October 2021 / Published online: 3 November 2021

(c) Società Italiana di Patologia Vegetale (S.I.Pa.V.) 2021

Keywords Cyclamen persicum · Fusarium wilt · Turkey

Cyclamen persicum is a flowering species, widely cultivated as an ornamental plant worldwide. In May 2021, symptoms of Fusarium wilt, including wilting of leaves, root rot, vascular discoloration and plant death were observed in $30 \%$ of $C$. persicum plants, grown in a 5 decares greenhouse in Bursa province, Turkey. Symptomatic tissues from 10 plants were surface-sterilized with $1 \% \mathrm{NaOCl}$ solution for $3 \mathrm{~min}$ and placed onto potato dextrose agar (PDA). The colonies developed were pale white to pink, floccose with abundant aerial mycelia. Conidiophores from the aerial mycelia often had single phialides. Macroconidia produced in sporodochia were hyaline, slightly curved, 3 to 5 septate and 29.5-41.2 $\times$ 7.3-9.8 $\mu \mathrm{m}(\mathrm{n}=30)$ with basal foot cells shaped to pointed and apical cells tapered and curved. Micronidia [7.4-14.8 $\times$ 3.9-5.8 $\mu \mathrm{m}(\mathrm{n}=30)]$ formed on short monophialides in falseheads were aseptate, elliptical or kidney shaped. Chlamydospores were terminal or intercalary in position and 7-12 $\mu \mathrm{m}$ in size. These characteristics were consistent with the description of F. oxysporum by Leslie and Summerell (2006). Also, RPB2 and EF1- $\alpha$ genes of the reference isolate Foc4 were sequenced with primers RPB2for/RPB2rev and EF1/EF2 and deposited in GenBank (accession Nos. MZ676956 for RPB2 and MZ676955 for EF1- $\alpha$ ) (O'Donnell et al. 2010; Staats et al. 2005). BLAST analysis showed $99.9-100 \%$ similarity to those (RPB2: LN828096, EF1- $\alpha$ : FJ985420) of $F$. oxysporum in GenBank. Also, EF1- $\alpha$ sequence shared $99.82 \%$ homology with known $F$. oxysporum f. sp. cyclaminis isolate MIAE01686 (accession No. KU128940). The phylogenetic analysis results showed the close genetic relationship of Foc4

Harun Bayraktar

bayrakta@agri.ankara.edu.tr

1 Atatürk Central Horticultural Research Institute, 77102 Yalova, Turkey

2 Department of Plant Protection, Faculty of Agriculture, Ankara University, 06110 Ankara, Turkey with other strains of $F$. oxysporum. Pathogenicity tests were performed on 5-6 leaf seedlings of $C$. persicum. Six seedlings were inoculated by dipping their wounded roots for $30 \mathrm{~min}$ in a spore suspension of $10^{6}$ spore $/ \mathrm{ml}$. Control plants were inoculated with sterile distilled water. The plants were transplanted into pots and placed at $23 \pm 1^{\circ} \mathrm{C}$ in $12 \mathrm{~h}$ photoperiod. After 3 weeks, typical wilt symptoms were observed on inoculated plants, but no symptoms were observed on control plants. Fusarium oxysporum was re-isolated from the inoculated seedlings, thus fulfilling Koch's postulates. To our knowledge, this is the first report of $F$. oxysporum as the causal agent of Fusarium wilt on Cyclamen persicum in Turkey.

\section{Declarations}

Ethical statement This article does not contain any studies with human participants or animals.

Conflict of interest All authors declare that they have no conflict of interests.

\section{References}

Leslie JF, Summerell BA (2006) The Fusarium laboratory manual. Blackwell Publishing, Iowa, USA

O’Donnell K, Sutton DA, Rinaldi MG, Sarver BA, Balajee SA, Schroers HJ, Summerbell RC, Robert VA, Crous PW, Zhang N, Aoki T (2010) Internet-accessible DNA sequence database for identifying fusaria from human and animal infections. J Clin Microbiol 48:3708-3718

Staats M, van Baarlen P, van Kan JA (2005) Molecular phylogeny of the plant pathogenic genus Botrytis and the evolution of host specificity. Mol Biol Evol 22:333-346

Publisher's Note Springer Nature remains neutral with regard to jurisdictional claims in published maps and institutional affiliations. 